the blunt dissection with this instrument has given the good results obtained.

The features recommending this new snare are as follows: 1. It is strong, heavy and will not get out of order. 2. It locks together, instead of having screws or fisteners. 3. It is easily kept clean. 4. It is easily and quickly threaded. 5. It has an entirely new device for fastening the wire; when once clamped the harder you pull the tigliter it becomes.

Shreve Building.

\section{DIFFUSE IDIOPATHIC HYPERTROPHY OF THE MAMMARY GLANDS OF THE FEMALE *}

A REPORT OF A NEW CASE AND A CONSIDERATION OF THE ETIOLOGY AND PATJIOLOGY BASIED ON DATA OF RECORDED CASES

HENRY ALBERT, M.D. IOWA CITY, IOWA

\section{REPORT OF CASES}

The following clinical history of the case was furnished by Dr. H. Matthey of Davenport, Iowa:

Patient. - The patient, a girl 13 years of age, when examined August, 1903, was 5 feet and 5 inches tall, weighed 101 pounds and was found to be of a nervous temperament.

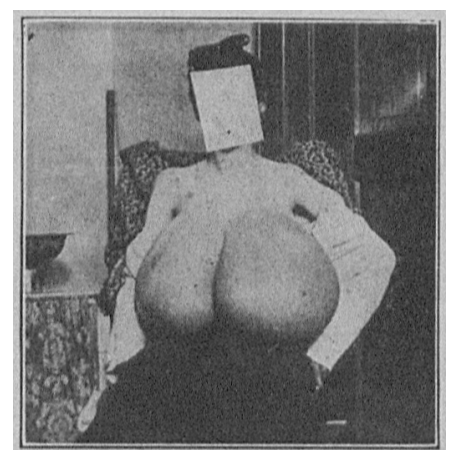

Fig. 1.- Patlent with mammary hypertrophy: from photograph talien shortly before amputation of the left gland.

Family History.-The patient's parents were both living and well, hẹr father being 39 years of age and her mother 36 . She lad one brother and one sister, both living. In none of these other members of the family was there any undue enlargement of the mammary glands.

Personal History.-The patient had had the usual diseases of childhood. Enlargement of the brensts began in the early part of Jume, 1003, and continued at suc h a rate that in August she was taken to a physician who estimated that each brenst weighel alont 8 pounds. Pressure applied by means of a landage and maintained for several months was without benefit. In October when the patient first consulted me, the breasts weighed about 12 pounds each. Ope:ation was advised, but refused. She now drifted into the liands of quacks who treated the condition in various way, without giving any relief. In $J u l y, 1904$, she returned to me in poor general condition, feeble, anemic and emnciated. Her weight was 100 pounds, a little more than half of which was contributed by the breasts. Because of these facts, it was deemed advisable to remove only one breast at a time (Fig. 1). The first operation was undertaken July 14, 1004. The amputated left breast weighed 28 pounds. After being two weeks in the hospital, she was allowed to go home to recuperate for the

- Read in the Section on Pathology and Physiology of the American Medical Associntion, at the Sixty-first Annual Session beld at St. Louls, June, 1010. second operation. At this time her weight was 79 pounds. During the following two weeks she gained 13 pounds and returned for the operation, weighing at this time 92 pounds. The right breast was amputated Aug. 12 , 1904. It weighed 26 pounds. Recovery was uneventful, healing being by primary intention. Pationt remained in hospital two weeks and returned home in good general health and weighing 75 pounds. Six weeks after the second operation she menstruated for the first time and lans been regular since. She was married in 1909 and has been delivered of $\mathfrak{a}$ six-months developed rhild since. At present the general health of patient is good; weight, 115 pounds; height, 5 feet 9 inches.

\section{PATHOLOGY OF SPECIMENS}

This was essentially the same for the two glands.

Gross Pathology.-Shape: Both glands, wheh were rather spherical in shape and pendulous while attached to the body of the patient, became considerably flattened out between the skin surface and the base after their removal.

Size: The left gland, which was the larger, was, after removal from the body, 18 inches in diameter and 8 inches in thickness. Its greatest circumference was 58 inches and it

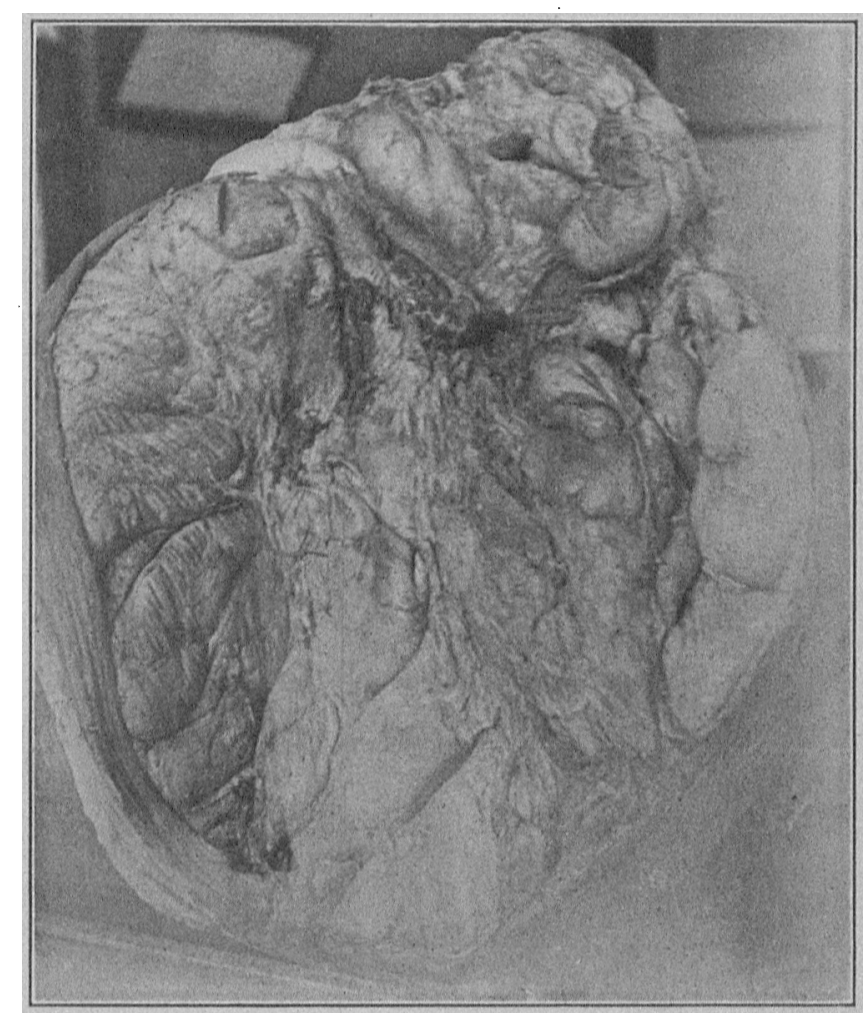

Fig. 2.--Base of left gland, showing lobulated and cncapsulated abpearunce.

weighed 28 pounis. The right gland was 14 inches in diameter, $71 / 2$ inches in thickness; its greatest circumference was 45 inches and weighed 26 pounds.

Surface Contour: The skin surface was smooth, being tightly stretched over the underlying gland substance. The nipple of each of the glands had become flattened out and the areola more difruse, but less distinct than normally. The bases of the glands were distinctly lobulated; the lobulated areas vary. ing from one to four inches in diameter (Fig. 2). The outlines of the glands at the base were so distinct as to be apparently well encapsulated.

Consistency: The glands were moderately soft in consistency. This was quite uniform throughout the gland mass, although on cut section certain areas were found to be much more firm in consistency than others. These were not distinct and circumscribed, but fused gradually with the more soft areas. A number of rather large ducts, some with a diameter of as much as $1 / 8$ of an inch were visible on the cut surface. The 
subcutuneous adipose tissue had entirely disappenred. Only a small amount of fat was still noticeable about the base of the gland (Fig. 3).

color: The cut surface of the tumor was of a whitishpinkish gray color. The pinkish tint was more marked in the firm than in the soft areas.

Mieroscopic Patholoyy-Section from Firm Portion of (i)and: The section consisted principully of full developed dibrons connective tissue with a fair number of capillary bloodvessels. The gland elentents were found somewhat grouped in areas, corresponding to the lobules; the ncini, however, were much more widely separated than in the normal gland. 'The acini which were of variable size, some quite large and many dilated, were lined by a single layer of a low colummar (almost cuboidal) gland epithelium, resting on a basement membrane consisting of flat cells. The lumen was free from

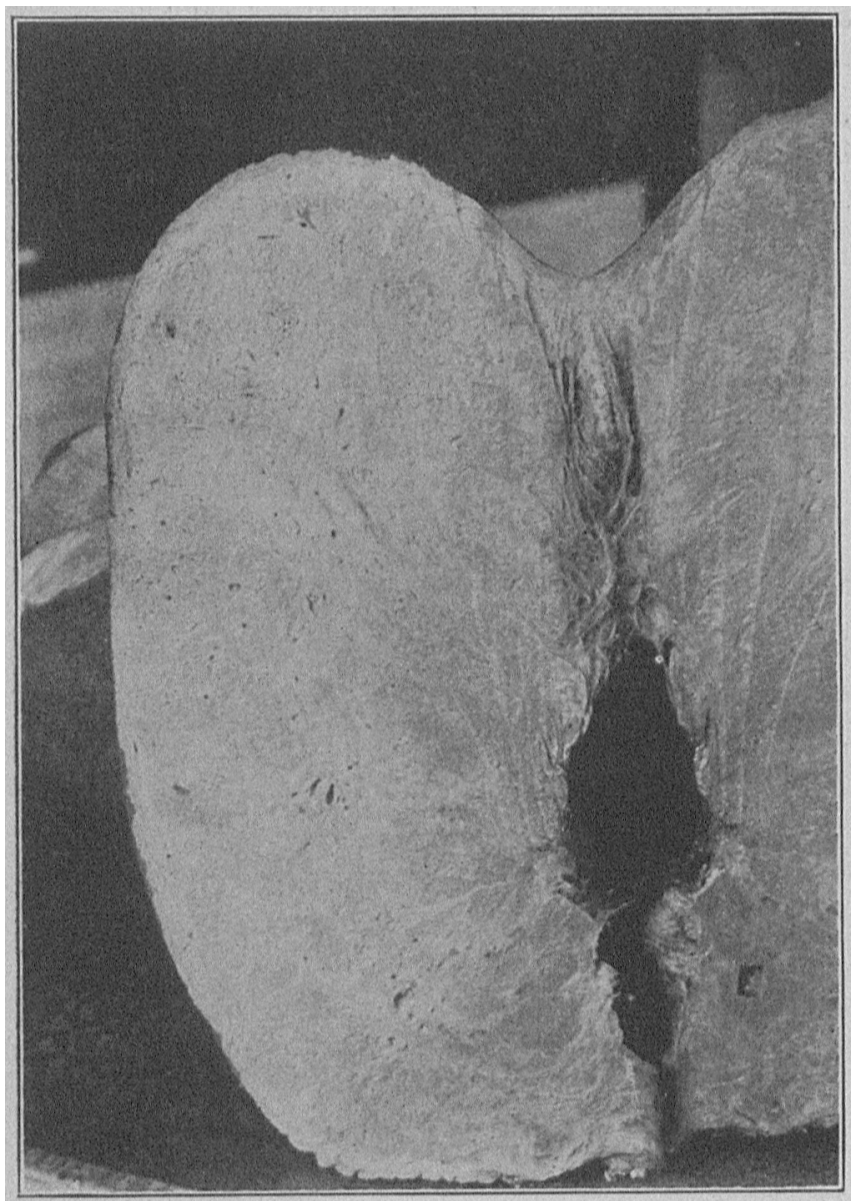

Fig. 3.-Cut surface of right glnnd, showing derk areas of glandular tissue. light areas of more pure connective tisste, and open spaces representing diluted duets.

contents, except in a fow in which debris, consisting of degenerated and desquamated colls, was found.

Section from Soft Light.Colored l'ortion of Gland: This scetion consisted almost entirely of fibrous commective tissue with only a very few gland elements. The connective tissue, which contained only a few widely separated nuclei, was somewhat edematous. There were numerous enpillary blood-vessels and a number of fat cells.

Section through Skin, including a Portion of the Gland Substance of Medium Consistency: This section showed the connective tissue of the hypertrophied gland to be continuous with that of the subcutaneous tissue and the corium. Except for a few fat cells, the subeutaneous adipose tissue had entirely disappeared. The elastic fibers of the corium were fully as abundant as in the normal skin. I was unable to find any elastic fibers in the substance of the gland proper except, of course, in the larger blood-vessels.
Scetion from IBase of Gland, Including the "Capsule": The "applatent" capsule of the gland was found to consist of condensed grland substance eonsisting of both gland and connective tissue elements. The glands were somewhat flattencid.

summary of Pathology. - The process was a difruse liypertrophy affecting all parts of both glands rather uniformly and involving both the glandular and comective tissue elements, the incrense affecting principally the latter. The gland acini were lined by a single layer of low eolummar (almost euboidal) epithelium, were larger than normal and more willely separated by intervening comnective tissue, which was of the fully developed fibrous type. Capillary blood-vessels were numerons.

\section{REVIEW OF CASLS REPOR'TEI)}

Diffuse idiopathic hypertroply of the mammary glands is a rare conclition. Several authors have collected clata from a number of cases, but no attempt to collect all cases reported has been made for some time. In 1902: Kirchheim ${ }^{1}$ collected most of the cases reported up to that time. I have reviewed the literature and have

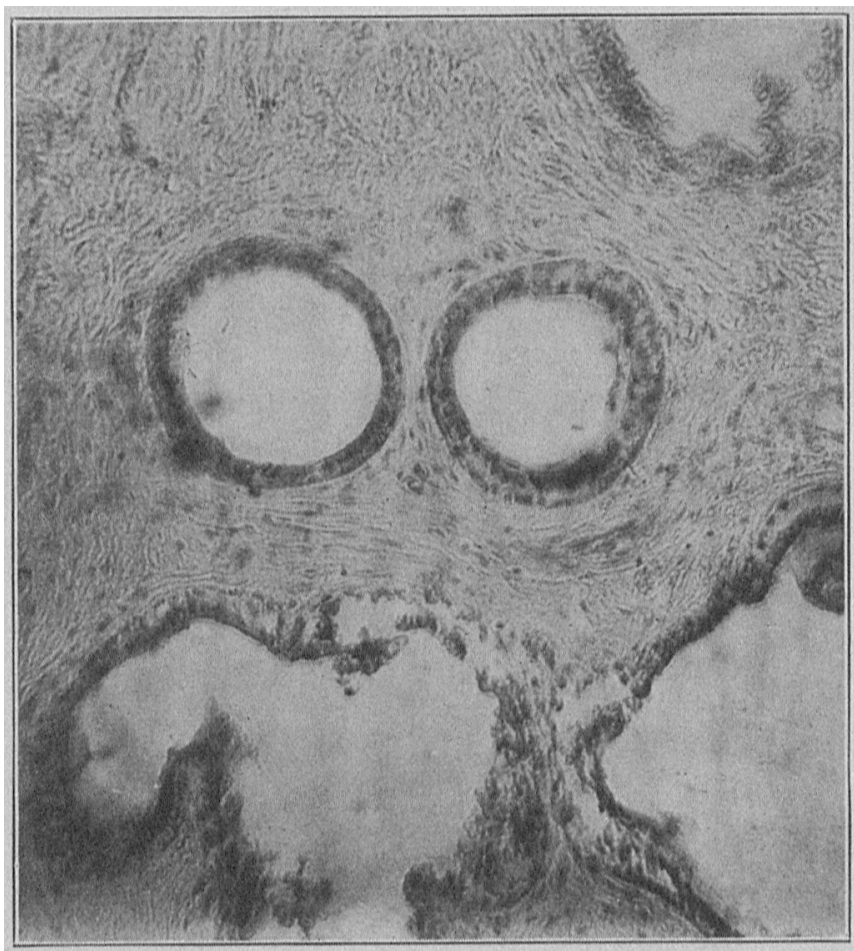

Fig. 4.-Photomicrograph of dense glandular portlon of right pland showing lrregular varlously shaped acini lined by a single layer of low columnar epltbelium.

made an attempt to collect all cases reported to date and have summarized the essential data from these cases. so far as such has been available. In some instances i have not been able to secure the original report. In many more the data was very meager. In the majority of cases no description of the pathologic process was given, and I have little doubt but that I have included some cases that are not instances of "true" hypertrophy. I have purposely omitted a case of excessive adiposity of the mamma, diagnosed clinically as difiuse hypertrophy, of which I have the specimen, and another case concerning which I have been informed but of which no pathologic examination was made. I have not included in this paper the eases of mild degree of hypertrophy of the mammae of the male (gynecomastia), or of senile parenchymiatous hypertroplyy (Bloodgood ${ }^{2}$ ), partial or

1. KIrchhosm : Arch. f. klln. Chir., 1902, lxvill. 582.

2 Bloodgoor : Surg., Gyne: and Obst., 1000. 111, 721. 
localized hypertrophy, and the still more mild types of so-called hypertrophy occasionally seen associated with pulmonary tuberculosis.

Although I have summarized the principal data from the cases reported, I shall in this paper limit the consideration to the etiology and pathology of the conclition.

Number of Cases Reported.-Aside from the one which I have just described, I have been able to collect reports of sixty-nine other cases of difluse hypertroply of the female mamme. Of thesc seventy cases sixty-two were bilateral and six unilateral, three affecting the right and three the left gland. In two instances I was unable to learn which glands were affected.

Age.-Although Bittner ${ }^{3}$ reported a case of hyperplasia (probably not true hypertrophy) of the mammary gland in a girl 6 montlis old, the age limit of the reported cases of true hypertrophy extends from 11 to 42 years, with practically every intervening year represented. The vast majority begin to develop about the time or soon after puberty or during gestation. Filty. eight per cent. of the cases not associated with gestation leveloped between the ages of 11 and 16 and 40 per cent. during the fourteenth and fifteenth year's of age.

Classification of Cases._Cases of idiopathic hypertrophy may be classified into (1) those associated with gestation and (i) those not associated with gestation, most of which are closely related to puberty.

1. Gestation Idiopalhic Hypertrophy.-Of the seventy cases eighteen were of this type. Fourteen of these were bilateral and four unilateral. 'The relation to gestation is clearly indicated by the fact that, after the termination of pregnancy, the condition subsides, although it does not return completely to the normal, and that it frequently reappears during subsequent pregnancics. The enlargement usually begins during the first pregnuncy. Sometimes, however, it occurs for the first time luring the second or thisd. In one instance it did not develop until the eighth pregnancy.

2. Cases Not Associated with Gestation.-The relation of puberty to cases of hypertrophy is suggested hy the fact that 58 per cent. of the cases not associated with gestation developed between the ages of 11 and 16, the perjod during which puberty ordinarily occurs, and that in n large number of cases menstruation did not. set in intil alter the enlinged glands were removed. In many cases, however, there seems to be no association with either pulserty or gestation.

Eliology.-The real cause of this condition is unknown. Such factors as heredity, traumatism, undue sexral activity, general malnutrition, ete, which have been mentioned in connection with the process, seem to have nothing to do with it. Pathologically the process appears to be simply an excessive developnent of the normal enlargement as seen especially at puberty and during gestation. Presumably the causes which produce the numal enlargement are also at work on this pathologic form, the latter being produced either because of a large amount (or unclue artivity) of the same canse, or a lack of the inhibitory influences which, under normal conlitions, limit the extent of the enlargement.

liecent experimental work has shown that the normal enlargenent of the glands is not always due to the same "ause. The work of Lane-Claypon and Starling" in producing an increase in the size of the mammary gland of

3. Bittner, iv. I Inll von IIyperplasle betder Mamma bel cinen 6 Monate alten Mildchen, l'rag. med. Wehnschr., 1805, xx, 402.

4. Lane-clayon and Staljing: An Fxperimentul Enquiry into

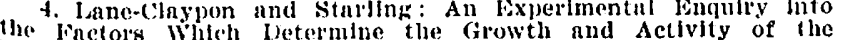
Inmary Giands, Proc. Loy. Soc., London, 1000, Ixxvil, B, 605-522. virgin rablits by the injection of extracts from the body of rabbit fetuses has shown very conclusively that the enlargement of the mamma during gestation is through the action of a hormone produced in the fetus. That this may also be the cause of the jdiopathic gestation hypertrophy is very probable, especially inasmuch as thit condition subsides after the termination of the pregninnt state.

'The cause of the normal enlargement of the glands at puberty is not so well understood. The evidence at hand seems to indicate that a hormone in the ovaries is the principal factor responsible for the development of the mammary glands outside of pregnancy. If this proves to be the case it would seem that removal of portions of the ovaries would be indicated in the treatment of the condition. Up to the present time the only treatment that has been of value is amputation of the glands. Removal of portions of the ovaries has not been tried, so far as I know.

It is very doubtful whether or not the cessation or irregularity of the menses, noticed shortly before and rluring the lypertrophy in many of the cases not associated with gestation, is of etiologic significance. This may simply be a symptom of the condition, as it is a symptom of other diseases in which the vitality is lowered. On the other hand is to be noted the fact that the general health is usually not affected until aiter the discase is well advanced, whereas the cessation of the menses is frequently of sudden occurrence several months before the glands begin to enlarge

Gross Pathologic Morphology.-Shape: The enlarged glands stand out prominently from the chest, wall for some time. Later their weight causes them to become pendent and often pedunculated, the gland substance assuming a rather spherical mass, drawn away from the muscles of the chest and hanging over the front of the abdomen, sometimes as far down as the knees. Their large size frequently causes the patient much discomfort and sometimes necessitates the patient remaining in a recumbent position.

Size: The size of the different glands may be compared (1) by their greatest circumference and (2) by their weight.

1. The greatest circumference of the individual glands for which figures are available varies from $201 / 2$ inches to $511 / 2$ inches, the average being $311 / 2$ inches. 'The average circumference of the hypertrophied left glands is one inch more than the right.

2 . The weight of individual glands varies from $11 / 3$ jounds to 64 pounds with an avernge per gland (of all (a) hined glands of cases of bilateral hypertrophy varies from three pounds to 124 pounds (Durston's case) with an average of 37 pounds. In most cases and on a general average, the left gland weighed a little more than the right. The average weight of the gland in the cases of unilateral hypertrophy is $\mathbf{1 5}$ pounds. In the cases l'ported by Durston and myself the weight of the two glands exceeded the weight of the remainder of the body.

Surface Contour: The surface of the glands is quite smooth, and skin tightly drawn. The stretching of the skin usually causes the nipples to be fiattened out. In one instance they were reported as being retracted; in two, as having become enlarged-in Delfis ${ }^{30}$ case, as large as a hen's egg. The pigmented areas also become Jess definite and distinct as the skin becomes stretched. The

5. Durston: 1'bll. Tr. Roy. Soc., London, 1669

i. Delits: jour. de physlol. exper. de Magendie, 1825. 
skin remains quite freely movable over the underlying gland, even though the subcutaneous fat tends to disappear and the connective tissue of the skin gradually fuses with that of the gland. In the later stages, the skin may become thick and hard. In many instances the superficial veins become very large and stand out prominently as blue streaks.

Consistency: During the early stages the hypertrophic glands are firm and elastie, as they are during the normal enlurgement at puberty or during the early part of gestation. Later, when they become larger and pendent, they also become flaceid. At first the glands usually feel somewhat nodular; later, however, these tend to disappear. Even when the process feels quite diffusely uniform through the skin, the cut surface may show areas considerably more firm in consistency than others. Such areas diffuse into one another gradually.

Color: The color of the cut surface of the hyper. trophic gland in the few cases in which it has been noted, is apparently the same as under normal conditions.

Microscopic Pathologic Morphology.-Unfortunately, microscopic examinations of the specimens were made in only about twenty of the cases. In all of the cases not associated with gestation, it is recorded that there is an increase of both the glandular and the connective tissue elements. In most instances the connective tissue is reported as being principally increased, although in four cases special mention is made of the marked glandular increase. The gland acini are usually described as being larger than normal, more widely separated and sometimes found to be lined with several layers of gland epithelium. I am inolined to think that this last-mentioned phenomenon is due prineipally to the thickness of the section and the cutting of the acini in an oblique manner. In many instances the glands are considerably dilated and contain granular degenerated material. Such changes in the glands have been likened to the changes that occur in the glands during the early stages of pregnancy. The fibrous connective tissue is uswally described as being of the fully developed type with, as a rule, very few nuclei, although some are mentioned as being quite cellular-which may, of course, have heen due to an associated inflammation. In the three cases of idiopathic gestation hypertrophy in which a microscopic examination was recorded, the microscopic findings were like those of the mammary gland during pregnancy. Sweb findings, indeed, may rensonably be expected.

Pathological Plyysiology.-Gestation hypertrophic glands usually functionate as do the normal ones, although it is often difficult to nurse the infant because of the flattening out of the nipple. Those not associnted with hypertrophy are functionless during non-pregnant conditions, although it has been possille to squeeze colostrum-like fluid from the ducts in some cases. Usulally, also there is no lactation after the birth of a full-terim child. In scveral instances, however, there was normal lactation in the glands that had been enlarged before the pregnant state. In one case associated with gestation, there was marked galactorrhea of eight montls' duration.

Nature of Pathologic Condition.-Idiopathic hynertrophy has heen regarded varionsly by different anthors as a circulatory (edema), an inflammatory, a neoplastic or as a sinple hypertrophic proress.

In favor of its being an edematous process is the rather sudden onset that has been reported in several cases. In the cases of Durstons ${ }^{5}$ and Delbet, ${ }^{3}$ for in-

\footnotetext{
7. Delbet: 'Trulte de Chirurgic (Duplay Iteclus), v.
}

stance, the patients retired in the evening, slept quietly as usual and in the morning on awaking found themselves scarcely able to turn around. When they tried to get up, the weight of the suddenly enlarged glands caused them to sink back. Usually, however, the onset is very gradual.

Opposed to its being a circulatory process is the fact that there was no mention made of pitting on pressure in the cases reported. nor has the tissue of the glands removed been reported as edematous. For a long time the enlarged glands are firm and elastic and stand out prominently from the body; this would not be the anse in edema. The increase in connective tissue following edema is in the nature of a fibrosis rather than an increase of all of the tissue elements. The slight edema which I found in my specimens and which accounts in part for their great shrinkage when placed in formaldehyd solution may readily be explained by the interference with circulation caused by the pendant glands.

There is really no evidence in favor of its being an inflammatory process. The pain sometimes noticed may readily be accounted for on the basis of pressure and a stretching of the nerves.

The neoplastic theory has several supporters. In Porter's ${ }^{8}$ case, in which the glands weighed 17 and 43 pounds respectively, the diagnosis made was intracanalicular fibroma. Kirchheim ${ }^{1}$ regards it as a diffuse fibroma. It is true that a section of the hypertrophic gland may be like one from a case of adenofibroma, but a tumor is usually thought of as a more localized and circumscribed process, especially if it is benign. The idiopathic hypertrophy, however, which pathologically is benign, is a diffuse process involving all parts of the gland. The fact that it may begin as a rather localized process, limited to a certain part of the gland, simply means that such represents the beginning point, probably the most susceptib]e tissue, just as one gland sometimes becomes involved before the other.

Considered from all standpoints, it must be regarded as a simple hypertrophic process involving all of the elements of the gland, but especially the part which at the time, is the most actively growing tissue, namely, the glandular tissue during gestation and the connective tissue at other times, especially during puberty.

The question has been raised as to whether or not cases of unilateral enlargements are cases of true hypertrophy. With a clinical history like those of bilateral hypertrophy, with the same pathologic condition, so far as we know, and an average weight of 15 pounds as against 17 pounds in case of the bilateral type, there is no reason, it seems to me, why they should not be regarded as identical. Indeed, in Van Swieten's case, the unusual enlargement of one breast which occurred during pregnancy subsided after the termination of gestation. During the second pregnancy it again enlarged.

Associnted Pathologic Conditions. - When the glands become of large size, the friction of the glands against a bracing bandage or supporting elothing frequently causes an excoriation of the epidermis chiefly at the most dependent portion. Such friction is apt to be followed by inflammation, abscess and fistula formation, eczema, erysipelas and gangrene. In one case, there was a hernial protrusion of gland-substance through an excoriated opening. Although Billroth ${ }^{10}$ reported a case

8. Porter: Boston Med. and Surg. Jour., March 3, 1802.

8. Polter : Boston Med. and Surg. Jour., March 3, 1802 . cognoscendls et surandis morbis, Jeyden, 1704,

cognoscendls et sulrandis morbis, Jeyden, 1704 , A lv.
10. Blllroth : Krankheiten der Brustdrisen, Deutsche Chlrurgie, 10. Blllroth : Krankheit
1880 , Instalment xll, 69. 
of sarcoma and Bloolgood ${ }^{2}$ a case of carcinoma in a gland idiopathically hypertrophied, such glands do not appear to be any more prone to malignant tumor formation than under other conditions. In several cases the axillary lympli-nodes were found to be enlarged. In the majority of these cases, there was some acute inflammation of the manmm which readily accounted for the involvement of the lymph-nodes. In several, however, therc was no recognizable acute inflammation of the Illamma. Even in such cases, the lymph-node enlargement was of a fibrous (chronic inflammatory) character. In no case has there been any metastatic formation of the hypertrophic mamma.

\section{GENIBRAL, SUMMIARY}

1. Of the eventy reported cases of diffuse hypertrophy of the fomale numma, in eighteen the enlargement vecurred during gestation; most of the others occurred about the time of or soon after puberty.

2. Of the seventy cases, sixty-two were bilateral.

3. Filty-eight per cent. of the cases not associated with gestation developed between the ages of 11 and 16 and 40 per cent. during the ages of 14 and 15 .

4. The etiology of the condition is obscure. It is very probably clue to the action of the same hormones that produce the physiologic enlargements.

5. Pathologically, the condition is a simple diffuse hypertrophy, involving both glands and connective elements. 'The increase' in the gland elements occurs principally in the cases occurring during gestation, whereas the connective tissue increase usually predominates in those not associated with that condition. The process appears to be essentially an exaggeration or continuation of the enlargements that affeet the gland normally at puberty and during gestation.

6 . The weight of the glands varies from $1 \frac{1}{3}$ to 64 pounds, the average per gland of all cases being 17 pounds. In one instance, one of the glands weighed (34 pounds and both glinds, 124 pounds. In two instances the combined weight of the two glands exceeded the weight of the remainder of the body.

7. In cases associated with gestation, lactation is. as a rule, normal. In those hypertrophies not associated with gestation the glands seldom lunctionate, even after pregnancy.

Dubuque and Jeffergon Streets.

\section{AIBSTRACT OF JISCUSSION}

Dr. A. S. Warturn, Ann Arbor, Mich.: I slould like to ask Dr. Albert whether this woman was able to throw her mammary glands over her shoulder; a similar hypertrophy of the mammary gland is often seen in Hottentot women who are able to throw their breasts over their shoulders and suckle their children, who are carried in slings on their backs. i should also like to know to what type of man this woman corresponded. Did she lave any fentures that go with the Australoid type or Negroid type? Would there be any antliropologic interest in this cuse as an instance of reversion?

Dr. James J. Termis, Galveston: Was there any pain nssociated with the condition? I remember seeing specimens from a somewhat similar case in the early part of this year. The patient, a girl aged about eighteen, had what was diagnosed as difluse virginal hypertropliy of the breast. Both breasts enlarged but did not weigh more than two pounds each. One breast had to be removed, however, on account of excessive pain, the cause of which was never discovered; but on removal of the first breast, the pain disappenred and the otler breast gradually grew smaller in size. Sections pre- sented an appearance practically identical with that of the sections in Dr. Alber't's case.

Dr. Greer Bavaliman, Richmond, Va.: I saw a case in November, 1903, with Dr. George B. Johnson, in a young white womnn. The left breast weighed $10 \frac{1 / 4}{4}$ pounds; the right $73 / 4$. The microscopic findings were almost the same as those in Dr. Albert's case-a true hypertrophy of the mamma-non. functionating, except that there was not so much dilatation of the acini and very little fat.

1)r. Henry Albeis, Iowa City, Iowa: The patient was not able to throw her breasts over her shoulders. I did not see the patient; but I made careful inquiry of the clinicinu as to any peculiarities suggestive of reversion and was in. formed that there were none; nor did her parents present any unusual appearance. There was no pain except that which may be readily explained by the enlarged size of the breast. In the reported cases, however, there are a number associated with severe pain, and in a few instances pain was present from the beginning of the process.

A patient whom I saw three or four weeks ago presented considerable enlargement of the mammary glands. A diagnosis of diffuse hypertrophy was made. The process began about a year ago, but it was only during the last three months that the pain had become extreme. On examining the glands microscopically after removal we found nothing but fatty and a little fibrous connective tissue. One of the cases in the literature contains a reference to the fact that the hypertrophy was not due to glandular, but to fatty increase.

\section{A STUDY OF MISTAKEN DIAGNOSES}

BASLD ON THE ANALYSIS OF 1,000 AUTOPSIES AND A COMPARISON WITH THE CLINICAL FINDINGS *

\section{RICHARD C. CABO'T, M.D. BOSTON}

The subject of this paper was suggested by my experiences in a weekly conference with senior medical students at the Harvard Medical School. At this conference the organs obtained from all the autopsies performed at the Massachusetts General Hospital during the week preceding are brought before the class. Before the demonstration of each set of organs I discuss with the students a typewritten summary of the clinical findings in the corresponding patient, including the history, the physical examinations; the reports on blood, urine, stomach contents and feces, the $x$-ray plates and all other data on which diagnosis was based during life. I never let anyone inform me beforehand of the autopsy findings. After we have committed ourselves definitely regarding the pathologic changes which we expect to find the hospital pathologist, Dr. Oscar Richardson, reads the autopsy protocol and demonstrates the organs.

In this exercise I have been forced once a week for three years to compare my diagnoses with post-mortem findings. It has proved so salutory and instructive, especially when I have been mistaken, that it has seemed to me well to summarize the results. of a large series of comparisons between the judgments arrived at by a careful study of clinical data and the anatomic conditions revealed post mortem.

\section{METHODS USED IN THE STUDY}

I must first explain, as nearly as I can, the plan followed. It is not a simple matter to collate ante-mortem

- Oration in Medicine read before the Section on Practice of Medicine of the American Medicnl Association, at the Sixty-first Annunl Session, beld at st. Iouls, June, 1010.

* Because of the space required, the article is slightly abbrevinted in THe Journat. It appears in full in the Transactions of the section and in the author's leprints. 